\title{
Considerations Regarding Work from Home and Telework
}

\author{
Brîndușa Oana TELEOACĂ VARTOLOMEI \\ Bucharest University of Economic Studies, Bucharest, Romania \\ brandusa.vartolomei@drept.ase.ro
}

\begin{abstract}
In the current pandemic conditions that have covered the whole world between individual contracts of special type, the contract with work at home has acquired a priority place. Likewise, telework, regulated in Romania since 2018 and considered a new form of work organization, has also proved its effectiveness. In this context, however, it is necessary to identify the advantages and disadvantages of working in the form of work at home or telework and to draw guidelines for future legislative changes in this area.
\end{abstract}

Keywords: home work; telework; teleworker; benefits; disadvantages; form of work organization.

\section{Introduction}

Certainly, in 2003 when the Labour Code came into force or in 2018, when Law No. 81 on the regulation of telework (Published in Official Gazette no. 296 from April 2, 2018) was adopted, no one imagined that in 2020 the entire planet would face the COVID-19 epidemic, and consequently, the need to make employment relations more flexible by effectively applying the legal provisions relating to these two legal institutions. If, as regards at work at home, the Labour Code is the normative act which expressly refers to this particular type of individual employment contract (O. I. Dumitru, A. Stoican, 2019), in the field of telework, the national legislation, namely Law No. $81 / 2018$, is mainly based on the provisions of the "Framework Agreement on Telework" (B. Vartolomei, 2008; C. Bratu, 2008; A. C. Ştefănescu, 2009; A. Ştefănescu, 2011; R. Dimitriu, 2016; M. E. Marica, 2019) concluded between UNICE - on behalf of the employers - and UEAPME , CEEP and CES - on the part of the professional organisations of employees, whose stated aim was to modernise the organisation of work and achieve the necessary balance between flexibility and security (I.T. Ştefănescu, 2017; A. Ţiclea, 2016).

Obviously - as in the case of the apprenticeship contract at work and the traineeship - Law No. 81/2018 is a special regulation in relation to that contained in the Labour Code.

\section{Internal regulations applicable to work at home and telework}

A) In accordance with the rules relating to work at home contained in Title II, art. 108-110 of the Labour Code, it has the following characteristics:

- the employee carries out the duties specific to the position he holds at his place of domicile and not at the employer's premise;

- the work schedule shall be determined unilaterally by the employee;

- the employer has the legal right to verify the activity carried out by the employee under the conditions laid down in the individual contract of employment by specifying the programme in which he can carry out the verification and the concrete way of carrying it out;

- the employer is obliged to ensure the transport to and from the employee's place of domicile of raw materials/materials and finished products.

Essentially, regardless of the objective pursued by the individual employment contract, its achievement is carried out at the employee's domicile/residence. 
B) According to the regulations contained in Law No. 81/2018 on the regulation of telework, it has the following characteristics:

- the employee shall regularly and voluntarily perform his duties specific to the position, occupation or occupation of the office which he holds, in a place other than the place of work organised by the employer, at least one day a month, using information and communication technology;

PICBE | 1218

- the work schedule shall be determined, in agreement with the employer, in accordance with the provisions of the individual employment contract, the internal regulation and/or the applicable collective agreement;

- the employer has the right to verify the activity of the tele-employee under the conditions laid down in the individual contract of employment, the internal regulation and/or the applicable collective contract of employment by indicating the programme in which he is able to verify the activity and the specific way in which the control is carried out;

- the parties shall determine the period and/or days on which the tele-employee carries out his activity at a workplace organised by the employer;

- the employer and the teleworking person identify in concrete terms the place/places of the telework activity;

- is the way of highlighting the hours of work provided by the tele-employee with the express indication that only full-time employees can provide overtime;

- the responsibilities of the parties in the field of occupational health and safety;

- the employer's obligation to ensure transport to and from the place of the telework of the materials used by the teleworking person in his activity, as appropriate;

- the employer's obligation to inform the tele-employee of the rules applicable to the protection of personal data;

- the measures that the employer takes to ensure that the tele-salaried person is not isolated from the rest of the employees (ensuring that he or she meets with co-workers on a regular basis);

- the conditions under which the employer bears the costs of working on a tele-work basis (in the absence of an agreement to the contrary between the parties);

- the obligation of the tele-employee to carry out his activity in accordance with his training and training, without endangering him or his or her injury or other persons who may be affected by his actions or omissions during the work process.

From a legal point of view, both the employee with work at home and the teleworking person enjoy the same rights and they have the same obligations - legal and contractual - as all other employees of the employer, who work within the unit. In addition, the employer, the employees' representatives and the competent authorities are entitled to verify the compliance of the legal provisions relating to health and safety at work and to employment relations by virtue of the provisions of the Labour Code, in Law No 81/2018 as well as in Law No. 108/1999 of the Labour Inspection.

Essentially, in the case of telework, work is performed using information and communication technology and, at the same time, is carried out in places other than those at the employer's establisment/domicile/residence (C. Lefter, O. I. Dumitru, 2009).

\section{Conclusions}

1. In conclusion, the legal regime applicable to the two types of individual employment contracts is similar, which differentiates them being mainly the following: 
In the case of the individual contract of employment with work at home, only one aspect appears essential: the work is carried out at the employee's residence and, acceptable, also at the residence of the employee.

In the case of telework are sine qua non 2 conditions:

- the way in which work is performed involves the use of information and communication;

- the work is carried out outside the employer's establishment/domicile/residence.

PICBE $\mid 1219$

Telework outside the employer's establishment/domicile/residence may also take place at the tele-employee's domicile/residence. What is expressly apparent from Article 9 (3) of Law No. $81 / 2018$ which refers to such a place.

This telework at home could be:

- incidental - meeting, however, the conditions for being one day a month - in which case, in our view, only the rules relating to telework remain applicable;

- with a certain continuity - a hypothesis in which we believe that both the rules in the field of telework and the rules on work at home must be applied in a rational corroboration. For example, in such a case, the work schedule shall be determined unilaterally by the tele-employee (Article 108 (2) of the Labour Code) and not by agreement with the employer as provided for in Article 2 (1) of the Law No. 81/2018.

2. It follows from the foregoing that a unified view of the types of employment contracts is necessary to characterise the work of the legislature in the future. Given that telework was regulated separately by special law, without rational reasons, it should be incorporated into the Labour Code (after work at home).

However, some improvements are needed. De lege ferenda:

A) In the case of work at home:

- expressly state that regular and voluntary nature for both parties is made clear that the refusal to carry out such an activity is not grounds for disciplinary sanction;

- identify, according to the CAEN code, the areas likely to work at home;

- ensure by the employer the possibility that those who carry out their remote activity can keep in touch or request and obtain information from their department colleagues or from the hierarchical superior within the unit;

- establish in particular how to access vocational training;

- specify the specific way of complying with the legal and conventional provisions on the protection of personal data and, in general, information, in so far as the exercise of the duties of service entails modern means of communication, access to the internet;

- establish the concrete way of organising working time;

- the rights and obligations of the parties corresponding to the rights and obligations of the other employees employed in the employing establishment are listed;

- identify the collective rights enjoyed by employees, emphasising that the pursuit of business outside the establishment does not impinge on the collective rights conferred on all employees.

B) In the case of telework:

- establish the possibility for the employer to refuse the employee's proposal concerning the pursuit of work under telework;

- respect by the employer the aspects of the employee's private life (both during the performance of his duties and outside them and outside the workplace); 
- specify the employer's assumption of the obligation, in addition to work equipment, to cover all direct costs arising from telework (including those with electricity, heat, gas, etc.);

- identify the restrictions on the tele-employee with regard to the use of equipment made available by the employer (i.e. the Internet) and the penalties that may be imposed on him in the event of non-compliance;

- establish the right of the employee to organise his own work schedule;

PICBE $\mid 1220$

- apply equal treatment in respect of the criteria for assessing the results of telework which must be equivalent to those of employees working in the workplaces organised by the employer but also with regard to the tele-employee's access to the same forms of professional training as the other employees of the employer.

- identify the rights and obligations of the tele-employee with regard to the use of computer means (such as the possibility and level of use for personal purposes; the prohibition for the employer to penetrate, where appropriate, into the sphere of the private life of the tele-employee; the obligation of the tele-employee to ensure the security of the data with which he operates on those means).

We use this opportunity to highlight that the above is not sufficient for a really comprehensive regulation (O.I. Dumitru, 2017). We refer to the fact that the legislature should include, also in the Labour Code any other special types of individual employment contracts, such as: "job sharing" (division of work between several employees), "employee sharing" (sharing of the employee by a group of employers), "on call" (with working time 0 ), and the voucher system.

3. In view of the advantages of working at home and telework, given that employees can harmoniously combine their private and professional life and the employer is able to reduce the costs of the work carried out, the disadvantages are mainly aimed at the reduced possibility of the employer to verify, in particular, the performance of the work rule as well as overtime (where appropriate) and the compliance by employees with the rules on health and safety at work. This is because, in the case of both work at home and in the case of telework, when the activity is carried out at his domicile/residence, the verification of compliance with the legal provisions on health and safety at work is subject to the prior agreement of the employee.

4. In the context of the COVID 19 epidemic, in Romania, through the legislation adopted between March and May 2020, the special rules contained in Law No. 81/2018 have been amended to ensure that employers have been able to unilaterally order, during the state of emergency - by unilateral decision of the employer - the pursuit of work at home or on a telework basis. At the time of the alert, work at home and telework was carried out only by concluding individual employment contracts with work at home or telework or following the signing of additional documents to existing individual employment contracts, and the employees' agreement to this effect was absolutely necessary.

5. Finally, in view of the current understanding of the concept of worker, as is apparent from the practice of the EU and the CJEU, it would be necessary to regulate in a chapter or in a special section the work performed under civil conventions for the provision of services specifying their particularities and, in particular, the system of payment of fees and contributions.

\section{References}


C. Bratu, Consideraţii privind munca la domiciliu, in Romanian Rewue on Labour Law no. 6/2008, p. 82- 90;

R. Dimitriu, Dreptul muncii. Anxietăţi ale prezentului, Rentrop şi Straton Publishing House, Bucharest, 2016, p. 141-146;

O.I. Dumitru, The European Company, Perspectives after Brexit, Juridical Tribune, vol. 7, no. 2, p. 134-146, 2017

O. I. Dumitru, A. Stoican, Business Law. Lecture notes, ASE Publishing House, Bucharest, 2019, p. $255-263$

C. Lefter, O. I. Dumitru, Reglementarea desfăşurării activităţilor economice de către persoane fizice autorizate, întreprinderi individuale şi întreprinderi familiale în baza Ordonanţei de urgenţă a Guvernului nr. 44/2008 - între noutate şi controversă, Romanian Review of Private Law no. 1/2009, Universul Juridic Publishing House, p. 104-116

M. E. Marica, Contractele de muncă atipice, Ed. Universul Juridic Publishing House, Bucharest, 2019, p. 280-330.

Ştefănescu, Munca la domiciliu şi telemunca. Drept intern şi comparat, Universul Juridic Publishing House, Bucharest, 2011, p. 188 - 222;

C. Ştefănescu, Telemunca, in Romanian Review on Labour Law no. 1/2009, p. 60-105;

I.T. Ştefănescu, Tratat teoretic şi practic de drept al muncii, the IV-th edition, Universul Juridic Publishing House, Bucharest, 2017, p. 326-328;

Ţiclea, Tratat de dreptul muncii. Legislaţie. Doctrină. Jurisprudenţă, the X-th edition, Universul Juridic Publishing House, Bucharest, 2016, p. 375-377.

B. Vartolomei, Telemunca - o nouă formă de organizare a muncii, in Romanian Rewue on Labour Law no. 2/2008, p. 62-70; 